\title{
Assessing the sustainability of fuelwood production and its potential impact on REDD+ in Burkina Faso
}

\section{Tanyi, Tabiagbor F.}

2017

Tanyi , T F , Etongo , D \& Abdoulaye , R 2017 , ' Assessing the sustainability of fuelwood production and its potential impact on REDD+ in Burkina Faso ' , International Journal of Environmental Studies, vol. 75 , no. 1 , pp. 186-200 . https://doi.org/10.1080/00207233.2017.1386435

http://hdl.handle.net/10138/311086

https://doi.org/10.1080/00207233.2017.1386435

acceptedVersion

Downloaded from Helda, University of Helsinki institutional repository.

This is an electronic reprint of the original article.

This reprint may differ from the original in pagination and typographic detail.

Please cite the original version. 


\title{
Assessing the sustainability of fuelwood production and its potential impact on REDD+ in Burkina Faso
}

Tabiagbor F Tanyi ${ }^{\mathrm{a}}$ Daniel Etongo ${ }^{\mathrm{a}, \mathrm{b}^{*}}$ and Rabdo Abdoulaye ${ }^{\mathrm{c}}$

${ }^{a}$ Viikki Tropical Resources Institute (VITRI), Department of Forest Sciences, University of Helsinki, Latokartanonkaari 7, P.O. Box 27, 00014 Helsinki, Finland,

bational Institute for Regional and Spatial Analysis (NIRSA), Maynooth University, Maynooth, Ireland and

${ }^{\mathrm{c}}$ AKVO, BP 625 Ouagadougou 1, Burkina Faso, West Africa

* Corresponding author, email: Daniel.Etongo@mu.ie

\begin{abstract}
The paper assesses the sustainability of fuelwood production and it implication on REDD+ in southern Burkina Faso. Data collection included a review of the forest management plans, an inventory of 135 plots in addition to silvicultural observations in three Forest Management Units. Fuelwood production data exceeded data from approved management plans by 50 percent. The conversion of forests to farmlands was observed in two parcels in addition to bush fire and grazing activities - an indication that minimum safeguard measures were not respected. The use of chain saws, capacity strengthening, political will and the effective implementation of approved management plans can all ensure the sustainability of fuelwood production.
\end{abstract}

KEYWORDS: Overharvesting, climate change, silviculture, Burkina Faso

\section{Introduction}

In Burkina Faso, an estimated $80 \%$ of the population depend on wood energy. It has been forecast that households will depend increasingly on fuelwood and charcoal during the next decade [1]. Despite the use of Joint Forest Management (JFM) through the participation of local communities [2], the sustainability question has become important because of challenges posed by climate change. Sustainable management of forests means conserving their benefits, for both present and future generations [3]; but many of the world's forests and woodlands, especially in the tropics are not managed sustainably [3]. In some countries the problem is the lack of appropriate forest policies, legislation, institutional frameworks and incentives to promote sustainable forest management (SFM). Other countries lack technical capacity. Even where approved management plans could ensure sustainable fuelwood production, ineffective implementation inspired by corruption and lawlessness causes failure, as seen in Central Africa [4].

In Burkina Faso, JFM or collaborative forest management (CFM) was introduced in the 1980s by the then Ministry of the Environment and Water Resources with financial and technical support from a joint FAO and UNDP project [5]. The main objective of JFM in Burkina Faso is to secure sustainable fuelwood production for household energy demand in both the cities and villages [6]. Furthermore, JFM in Burkina Faso was also intended to meet a wider range of socio-economic and ecological needs such as poverty alleviation through off-farm income, rural development and biodiversity conservation 
$[7,8]$. A recent study in Burkina Faso based on expert assessment raises concern on the sustainability of fuelwood production, since demand continues to increase [1].

If forests are a key source of greenhouse gas emissions and community forests under different forms of management constitute a quarter of all those in developing countries, it is difficult to tackle climate change without bringing these forests into $\operatorname{REDD}+{ }^{1}$ [9]. A key challenge is therefore to generate value from forestlands without overharvesting timber or converting to other uses, such as agriculture and pasture [10]. In principle, JFM areas can support the continuous provision of fuelwood to communities while maintaining the sustainability of other ecosystem goods and services [11].

In Burkina Faso, over $80 \%$ of the population depends on fuelwood as the main source of household energy [1,12]; other energy sources are little used if at all. The dominant source of energy for cooking is fuelwood and charcoal for $76.3 \%$ of the households in Ouagadougou, the capital city [12]. Although the Chantier d'Aménagement Forestier (CAF) model in Burkina Faso operates with approved forest management plans (FMPs), there are few studies on the sustainability of fuelwood production. Previous studies have focused on challenges of decentralized forest management, factors influencing access to forest products and participation in JFM [5,13,14]. Since all FMUs in the study area are now at different stages in their second rotation cycle, it becomes imperative to assess the sustainability of fuelwood production. This study focuses on three FMUs in Cassou zone, southern Burkina Faso and reviews the FMPs with emphasis on data from both fuelwood production and approved management plans. Additional data were collected through forest inventories and field observations and the paper offers recommendations for policy on the basis of the findings.

\section{Conceptual background}

According to the International Tropical Timber Organization (ITTO), SFM is a "process of managing forests to achieve one or more clearly specified objectives of management with regard to the production of a continuous flow of desired forest products and services, without undue reduction of its inherent values and future productivity and without undue undesirable effects on the physical and social environment" [16]. Accordingly, our study focuses on the sustainability of fuelwood production in JFM units in Burkina Faso by comparing data on approved management plans to that of fuelwood production data together with forest inventories and silvicultural observations.

Assessing the sustainability of fuelwood production requires a set of guiding principles [17]. The criteria [C] and indicators [I] used here are ones developed by the Centre for International Forestry Research (CIFOR) [18]. They have been used to evaluate sustainability in other forestry management cases also $[17,19,20]$.

The $\mathrm{C} \& \mathrm{I}$ in this study assessing the sustainability of fuelwood production in Burkina Faso are as follows: (i) allowable cut (AC) of wood as approved in FMPs, (ii) logged volume (LV) of fuelwood production data, (iii) tree diameter versus age of parcels, and (iv) silvicultural observations and other activities found within the FMUs, e.g., farmlands, grazing, etc. The difference between the AC and LV within an FMU, can either reduce or increase harvesting intensity of wood which is likely to affect the number of trees, basal area, or cubic metres of logged wood per ha [18,20,21].

Sustainable fuelwood production in this study implies the following: (i) logged volume of wood should not exceed the allowable cut of wood as prescribed in the management plans, (ii) tree diameter of logged FMUs is expected to decrease as the rotation year increases. For example, parcel 1 logged in

\footnotetext{
1. Reduce emissions from deforestation and forest degradation, and foster conservation, sustainable management of forests, and enhancement of forest carbon stocks (REDD+) [15].
} 
year one is expected to have trees of age 14 at the end of the fifteen-year rotation period, and (iii) FMUs should be void of farming activities, uncontrolled grazing and unauthorized burning/bush fire.

\section{Materials and methods}

\section{Description of study area}

This study was conducted in three FMUs of CAF Cassou located in the Ziro Province of Southern Burkina Faso (Figure 1). The study area lies between latitudes $11^{\circ} 35^{\prime}-11^{\circ} 55^{\prime}$ north and longitudes $2^{\circ} 00^{\prime}-2^{\circ} 25^{\prime}$ west of Burkina Faso and is located in the South-Sudanian climatic zone with temperatures ranging between $30-40^{\circ} \mathrm{C}$. The topography of this region consists of slightly undulating plateaus with altitude ranging between 260 and 360m above sea level [22]. The South-Sudanian zone receives the highest amount of rainfall in the country that fluctuates between 800 and $1000 \mathrm{~mm}$ per year.

Figure 1. Map of the study area showing inventoried FMUs in green

The north and central regions of Burkina Faso are exposed to drought and arid conditions which have provoked human migration to the southwestern regions; which offer better opportunities for rainfed agriculture and an all-year-round supply of fodder for livestock [23]. Approximately $70 \%$ of the population in Burkina Faso is rural and depends on agriculture and livestock [7]. This movement concerns two ethnic groups: Mossi from the Central Plateau and the Fulani from the northern region. The Fulani rear cattle as their main livelihood activity [24], and in the last four decades, this ethnic group have increasingly demonstrated interest in the cultivation of cereals such as sorghum, millet, sesame, etc.

The soil types are silty clay cambisols [25] which support tree growth with very little input. The vegetation includes dense savanna woodlands (savanna forests), sparsely wooded grassland, and shrubby forest lands [26]. There also exist some riverine compositions of gallery forests along water courses and swampy/marshy areas, supporting different tree species and vegetation types. The dominant tree species include Acacia species, Combretum species, Detarium microcarpum, Anogeissus leiocarpus, Burkea africana, Diospyros mespiliformis, Pteleopsis suberosa, Prosopis africana, Daniella oliveri, Diospyros mespilformis [27].

\section{The CAF model: A review of the forest management plans}

Forest management units - CAFs - within the framework of JFM were designed with the objective of combating unorthodox forest exploitation for fuelwood. In this model, each FMU ranging between 2000-4000 ha is divided into fifteen parcels of various sizes based on the number of trees and standing wood volume [5]. The partitioning of FMUs is designed to correspond to a rotation period of fifteen years. In principle, if parcel number 1 is logged in the first year, the tree age is expected to be at least fourteen years at the end of the rotation cycle - a time frame considered sufficient for the logged parcels to have regenerated and attained the required wood volume before the next rotation cycle begins $[28,29]$.

Minimum safeguard measures to ensure sustainability in fuelwood production include selective logging rather than clear cutting because only trees with a diameter (at breast height) ranging between $10-25 \mathrm{~cm}$ are approved to be logged. In addition, logging should be through a slant cut at $15 \mathrm{~cm}$ above the ground (see Figure 2) in order to facilitate regrowth of stumps. Only 50\% of the merchantable volume of wood in a parcel is allowed to be logged while logged parcels are to adopt prescribed 
burning while being protected from grazing for at least 3 years. Parcels with fewer than 200 trees/ha should not be harvested and should be improved through direct seeding [28,29].

Figure 2. Schematic representation of the CAF model in Burkina Faso

A coppice management method was adopted because the tree species are indigenous and possess the ability to regenerate naturally [22]. In terms of its organization, CAF Cassou consists of twelve FMUs partitioned into two; East and West and located in three administrative departments (Cassou, Bakata and Goa) across twenty-five villages in the Ziro province. In collaboration with the state's forestry and environmental service, the FMGs govern and manage the technical responsibility of CAF Cassou as guided by the FMPs. A technical team of forest engineers and technicians is responsible for implementing the approved management plans and also for fostering activities that promote biodiversity conservation and environmental protection [30].

\section{Data collection and processing}

Primary and secondary data were collected using different methods. The technical director of CAF Cassou made available the FMPs and data on fuelwood production from 1991 when this model became operational. The management plans were reviewed and members of the FMGs were contacted as resource persons for additional data on silvicultural practices, sources of disturbance in the forest and institutional challenges confronting JFM in the region.

A stratified method based on age class was used in the selection of FMUs that were inventoried (see Figure 1). During the forest inventory, data were collected on specific aspects. Each FMU is further divided into 15 parcels and in our study 3 sample plots were selected for tree inventory from each parcel. Based on this logic, 45 plots were inventoried in an FMU giving a total of 135 plots for the three selected FMUs. With assistance from the Centre for International Forestry Research (CIFOR) in Ouagadougou, Burkina Faso, shapefiles having the boundaries of FMUs and their various parcels were introduced into Google Earth.

In Google Earth, the select tool was used to select a total of three points in each parcel with the first plot selected at $50 \mathrm{~m}$ from the road or the edge of the parcel and the second and third points at a distance of $100 \mathrm{~m}$ from each other. This exercise was repeated for all the 3 FMUs and the data were saved and uploaded into a Global Positioning System (GPS) mobile device (Garmin 62s). The GPS mobile device was then used to trace all the corresponding points in the field. Where the selected point within a plot fell on a thick bush or marshy land, the nearest possible location away from that physical obstacle was selected in any direction for the inventory. The collected data were analysed using Microsoft Excel Version 2013 and the results presented as figures and tables.

\section{Results}

\section{Allowable cut $(A C)$ versus logged volume (LV)}

Results indicated that total logged volume $(\mathrm{TLV})^{2}$ of fuelwood exceeded total allowable cut (TAC) ${ }^{3}$ by $50 \%$ between 1991 and 2005 (Table 1). Instead of the $42,964 \mathrm{~m}^{3}$ of fuelwood as approved in FMPs,

\footnotetext{
${ }^{2}$ Total logged volume (TLV) and fuelwood production data will be used interchangeably.

${ }^{3}$ Total allowable cut (TAC) and approved fuelwood data on management plans are the same in the context of this study.
} 
fuelwood production data stood at $64,537 \mathrm{~m}^{3}$ - an indication that overharvesting occurred in FMU I, VIII and IX (see Table 1). Although the TAC was highest for FMU I, the TLV is almost as twice as the approved fuelwood data in the FMPs for FMU VIII (97\%). Therefore, FMU VIII corresponds to the unit with the highest TLV in excess followed by FMU I (61\%) and then FMU IX (14\%) respectively.

\section{Table 1 Here}

Aside from the individual FMUs that indicated an excess of TLV when compared to TAC, the pattern remains much the same for the period 1994 - 2004 for all the surveyed FMUs (Figure 3). This indicates that overharvesting was common in the study area despite the availability of approved management plans that stipulated the required quantities of fuelwood to be logged. In addition, the year 2002 recorded the highest overharvesting figure during which $8,872 \mathrm{~m}^{3}$ of wood were logged - a quantity considered 50\% in excess when compared to data on the approved management plans. On the other hand, the AAC in excess of ALV in 1993 could be linked to the fact that only information for FMU I was provided for that year.

Figure 3. Relationship between annual allowable cut (AAC) versus annual logged volume (ALV) $\left(\mathrm{m}^{3} /\right.$ year $)$

\section{Tree inventory}

In all, 8006 trees of different sizes were inventoried out of which 44\% were found in FMU I, $30 \%$ in FMU VIII and 26\% in FMU IX across three diameter classes (Table 2). In addition, more than 50\% trees were $<10 \mathrm{~cm}$ in diameter with fewer trees in the $\geq 25 \mathrm{~cm}$ diameter class. Such results indicate that the $50 \%$ trees of harvestable sizes expected to be kept as a minimum safeguard measure for the sustainability of fuelwood production have, so far, not been conserved.

\section{Table 2 Here}

A total of 741 stumps were inventoried of which $75 \%$ were in line with the harvesting prescription as indicated in the FMPs $(10-25 \mathrm{~cm}), 15 \%$ were above the required diameter $(>25 \mathrm{~cm})$ while $10 \%$ was $<10 \mathrm{~cm}$ (Table 2). Tree diameters in the Sahel are found within the $10-25 \mathrm{~cm}$ diameter class which explains why fewer trees exceeded $25 \mathrm{~cm}$. Aside from stumps, the basal area of trees was inventoried in 43 of the 45 selected parcels within the three FMUs. The least basal area $\left(1 \mathrm{~m}^{2} / \mathrm{ha}\right)$ was recorded in 6 parcels, 5 of these parcels being located in FMU IX and the sixth being in FMU I. The highest basal area $\left(6 \mathrm{~m}^{2} /\right.$ ha) was recorded in parcel 13 of FMU I (Fig. 4). On average, the basal areas across the FMUs stood at $3.1 \mathrm{~m}^{2} /$ ha (FMU I), $2.5 \mathrm{~m}^{2} /$ ha (FMU VIII) and $2.1 \mathrm{~m}^{2} /$ ha (FMU IX). FMU I recorded the highest basal area and FMU IX recorded the least among the inventoried trees although many differences did not occur across the FMUs.

Figure 4. Basal area inventoried across all parcels in the three selected FMUs

\section{Other activities observed in the forest}

Through observation, grazing was identified in $72 \%$ of all the inventoried plots (Table 3 ). In addition, unauthorized burning observed as scars on trees, burnt stumps and vegetation occurred in $61 \%$ of the 
135 plots inventoried. Furthermore, two of the parcels (parcel 6 in FMU VIII and 11 in FMU IX) were completely converted to farmlands - threatening the sustainability of fuelwood production in Burkina Faso.

\section{Table 3 Here}

\section{Discussion}

The discussion concerns three points: logging activity and overharvesting, tree diameter in inventoried FMUs and other activities observed in the forest such as bush fire, grazing, and conversion of forest to farmlands and the potential impact of all these activities on REDD+ in Burkina Faso.

\section{Logging activities and overharvesting of fuelwood}

The approved "slant cut" at $15 \mathrm{~cm}$ above the ground was not respected. Instead "ring cuts" dominated in the logged FMUs because of the use of rudimentary tools such as axe heads and cutlasses. [The disadvantage of "ring cuts" is the accumulation of water when it does rain, thereby increasing the chances of stump mortality. A change in technology from axe and cutlass to chain saw can easily provide the approved "slant cut" on logged wood. This is because trees in the Sahel can regenerate naturally but silvicultural practices such as logging specification can affect regrowth as corroborated by studies in Burkina Faso [22,29].

Illegal logging activities were observed in some of the FMUs during the field work, a practice that Nsita [31] describes as common in most JFM areas in developing countries. Some possible explanations for illegal logging activities include corruption, poor monitoring of common pool resources and lawlessness. Such activities could contribute to overharvesting and forest degradation thereby reducing the potential of trees to mitigate the effects of climate change by being carbon sinks. Studies in Sub-Saharan Africa and Europe agree that economic motivation undermines environmental consideration which causes violation of approved guidelines in FMPs [32-35].

Overharvesting occurred in more than $50 \%$ of forested land based on our results. This indicates that sustainable fuelwood production in Burkina Faso needs to be reinforced, as is corroborated by earlier studies in Cameroon [4] and Ghana [36]. Since approximately 80\% of the population in Burkina Faso depends on fuelwood, which is forecast to increase in the next decade [1], overharvesting is likely to continue. This is because amidst the wood energy crisis, alternative sources of household energy such as solar and wind energy are yet to be fully implemented partly because of poverty [37]. More than $46 \%$ of Burkina Faso's population lives below the national poverty threshold [38]. There is also government inertia; and another problem is environmental factors. Wind energy is identified as the least favoured form of renewable energy in Burkina Faso given the low wind speed in the country [39]. Furthermore, jatropha and several agricultural crops that are known to thrive on arid lands appear to be potential feed stocks for ethanol and biodiesel production. Only a few of these crops have been assessed from a technical and economic perspective in Burkina Faso as opposed to countries such as Brazil that for decades have benefited from the production and use of biodiesel [40; p. 10].

On the other hand, Burkina Faso's relatively higher solar energy potential continues to attract both national and international organizations and companies to invest in Solar Pv Off-Grid Power Systems across the country. In the year 2014, the European Investment Bank granted a twenty-year loan to support one of the largest photovoltaic power stations in sub-Saharan Africa. This huge project at the outskirts of Ouagadougou (capital city of Burkina Faso), is expected to be completed in August 2017 
[41]. Although such a project in principle is capable of reducing the proportion of those without access to electricity, it should be noted that less than 5\% of the rural population in Burkina Faso have access to electricity [41]. Furthermore, a recent study across 33 villages in Western Burkina Faso found out that photovoltaic solar energy systems were mostly used for local businesses [42]. Accordingly, wood energy is a major source of household energy for cooking especially in the rural areas. Therefore, overharvesting of fuelwood goes beyond the demand factor to include poverty, government inertia, urbanization, inadequate policies, poor monitoring of common pool resources and the lack of sufficient and affordable alternative energy sources [43].

\section{Tree diameter in inventoried FMUs}

Results indicated that the forests in the study area are largely dominated by smaller trees (56\% of class ' $A$ '). If the minimum safeguard measure to preserve $50 \%$ trees in each parcel that are of harvestable sizes are respected, fewer trees with $<10 \mathrm{~cm}$ in diameter will be found in each FMU, a confirmation that the approved management plans were not respected. Njepang [44] in his study of tropical moist forests in Cameroon also showed that the number of trees per hectare decreases from smaller to larger diameter class. Another study in the boreal forest indicated that tree diameter in uneven-aged forests had fewer trees as the diameter class increases [45]. Such findings indicate an increasing rate of forest degradation driven by unsustainable practices.

\section{Activities observed in the forests}

Herds of cattle were observed in the FMUs during the inventory and grazing reduces the potential of tree regrowth because most of the Sahelian tree species are palatable and constitute an important source of fodder for livestock. Fodder trees, e.g., pterocarpus erinaceus were observed to have been harvested shortly after sprouting by herdsmen and some of these affected trees could barely survive. Cattle harders often ran away when they encountered the inventory team in the FMUs with the fear that it was the forestry service officials looking for defaulters. Dayamba et al [29] in their study in Burkina Faso show that uncontrolled grazing can lead to forest degradation, unplanned forest lost or deforestation and also limit the recruitment of seedlings. Another study in Burkina Faso showed that the trampling effect of cattle on the soil reduces the infiltration capacity of water thereby reducing water available to plants [46].

Fire was also observed in the FMUs although prescribed early burning is recommended as a forest management technique that breaks seed dormancy. Some of the causes of bush fire mentioned by resource persons include cattle herders who camp at night in the forest using fire for warmth, and uncontrolled burning of agricultural waste by farmers close to the forest. Since average temperatures are relatively higher in the Sahel and accompanied by strong winds, the dry forest of Burkina Faso easily supports fire - a view reaffirmed by a study in Central Africa [47]. Furthermore, Sankaran et al [48] reported that lack of fire breaks at the edge of FMUs assists fires to spread across the forest in the event of an outbreak. The consequences therefore include the destruction of forest vegetation and increase in tree mortality - a finding that is supported by the Forestry Research Institute of Ghana [49].

The conversion of forest to farmlands is illegal but was observed in two parcels that were completely converted to farmlands. Field expansion into community forest areas in Burkina Faso is driven by several factors such as poor monitoring of forest, low farm productivity, scarcity of arable land owing to population increase especially in southern Burkina Faso - a view supported by two studies in sub-Saharan Africa [31,50]. Population increase combined with agricultural expansion and 
migration is a threat to environmental sustainability in the FMUs within this region [24]. The soils in the JFM are fertile and some farmers tend to expand their fields into forest areas in order to increase farm productivity in southern Burkina Faso [23]. The conversion of forest to farmlands not only releases carbon dioxide into the atmosphere but also affects the products and services derived from the forests. Therefore, if the current trend continues, deforestation and forest degradation are likely to undermine REDD+ in Burkina Faso. Bray et al [43] emphasize that JFM areas are vulnerable to encroachment by farmlands owing to the lack of capacity to monitor and to enforce existing laws.

There is also uncertainty about the boundaries of certain parcels as a result of the re-arrangement of the FMUs in 2008. Some small parcels were merged, the larger ones were divided, and others were given to community for farming activities. This re-arrangement has led to confusion even for CAF members. Some farmers are exploiting this weakness because the soils in this region and the climatic conditions are the best for rain-fed agriculture compared to other parts of the country. Land use scarcity has tempted some community members to take advantage of the poorly defined boundaries of the FMUs to establish their farms even within FMUs as identified in two parcels in our study. Yadav et al [51] argues that poorly defined forest boundaries make community forest vulnerable to agricultural expansion.

\section{Conclusion and policy recommendations}

Overharvesting is a major problem in the study area because fuelwood production data exceeded data from approved management plans by 50 percent. Deforestation and forest degradation (DD) were clearly observed through the conversion of forests to farmlands, overharvesting and the dominance of trees with smaller diameter- an indication that the management plans are not respected. In addition, the slant cut on logged wood was ignored and other minimum safeguard measures in the approved FMPs such as the requirement that $50 \%$ standing volume of wood of harvestable sizes must be preserved in each parcel. There was almost no evidence that there was nil harvesting in parcels with fewer than 200 trees/ha of which such parcels were to be accompanied by direct seeding. The implication is that DD does not only release carbon dioxide into the atmosphere but the FMUs are likely to suffer from degradation, thereby affecting ecosystem goods and services derived from the forests while reducing their potential to mitigate the effects of climate change. We recommend a switch of technology used in logging from the traditional axe and cutlass to chainsaw. This will not only provide a "slant cut" easily but also save time and labour. Despite the financial benefits received from the sale of fuelwood, the present level of fuelwood production in Burkina Faso is not sustainable. Therefore, to ensure the sustainability of fuelwood production in Burkina Faso needs more than approved management plans to include aspect of technological change, capacity strengthening, political will and the firm application of the law with appropriate penalties for infractions.

\section{Acknowledgements}

This research was funded by the Finnish Ministry of Foreign Affairs through the BIODEV Project (Building Biocarbon and Rural Development in West Africa). We would like to thank the CAF staff for making available to us the management plan of the Cassou zone and also for providing data of logged volume of wood. This paper is based on an MSc thesis in the Viikki Tropical Resources Institute (VITRI), Helsinki University, Finland. We also express profound gratitude to the CIFOR West Africa office for providing logistics support. Many thanks also to two anonymous reviewers and to the Editor for comments and suggestions. 


\section{References}

[1] Arevalo, J., 2016, Improving woodfuel governance in Burkina Fasao: The Experts' assessement. Renewable and Sustainable Energy Reviews, 57, 1398 - 1408.

[2] Delgado-Serrano, M., Vanwildemeersch, P., London, S., Ortiz-Guerrero, C.E., Semerena, R.E. and Rojas, M., 2016, Adapting prospective structural analysis to strengthen sustainable management and capacity building in community-based natural resource management contexts. Ecology and Society, 21(2), 36 http://dx.doi.org/10.5751/ES-08505-210236

[3] FAO, 2015, Global Forest Resources Assessment 2015. Rome: UN Food and Agriculture Organization. Available online at http://www.fao.org/forest-resources-assessment/en/ (accessed 18 October 2016).

[4] Cerutti, P.O., Nasi, R. and Tacconi, L., 2008, Sustainable forest management in Cameroon needs more than approved forest management plans. Ecology and Society, 13(2), 36.

http://www.ecologyandsociety.org/vol13/iss2/art36/

[5] Coulibaly-Lingani, P., Savadogo, P., Tigabu, M. and Odén, P.C., 2011, Factors influencing people's participation in the forest management program in Burkina Faso, West Africa. Forest Policy and Economics, 13(4), 292-302.

[6] Coulibaly-Lingani, P., Tigabu, M., Savadogo, P., Odén, P.C. and Ouadba, J.M, 2009, Determinants of access to forest products in southern Burkina Faso. Forest Policy and Economics, 11, 516-524.

[7] FIP (Forest Investment Program), 2012, REDD+ Preparation Plan. Ouagadougou, Burkina Faso: Ministry of Environment and Sustainable Development.

[8] Kambire, H.W., Djenontin, I.N.S., Kabore, A., Djoudi, H., Balinga, M.P.B., Zida, M., AssembeMvondo, S. and Brockhaus, M., 2015, La REDD+ et L'adaptation aux Changements Climatiques au Burkina Faso: Causes, Agents et Institutions. Bogor, Indonesia: CIFOR.

[9] RRI (Rights and Resources Initiative), 2014, What Future for Reform? Progress and Slowdown in Forest Tenure Reform Since 2002. Washington, DC: Rights and Resources Initiative.

[10] Hyde, W., Amacher, G. and Magrath, W., 1996, Deforestation and forest land use: theory, evidence and policy implications. World Bank Research Observer, 11(2), 223-248.

[11] Bélair, C., Ichikawa, K., Wong, B.Y.L. and Mulongoy, K.J., 2010, Sustainable use of biological diversity in socio-ecological production landscapes. Background to the 'Satoyama Initiative for the benefit of biodiversity and human well-being' (Vol. Technical Series no. 52). Montreal: Secretariat of the Convention on Biological Diversity.

[12] Ouedraogo, B., 2006, Household energy preferences for cooking in urban Ouagadougou. Energy Policy, 34, 3787-3795.

[13] Bouda, H., Savadogo, P., Tiveau, D. and Ouedraogo, B., 2011, State, Forest and Community:

Challenges of Democratically Decentralizing Forest Management in the Centre-West Region of Burkina Faso. Sustainable Development, 19(4), 275-288.

[14] Coulibaly-Lingani, P., Tigaba, M., Savadogo, P. and Odén, P.C., 2014, Participatory forest management in Burkina Faso: Members' perception of performance. Journal of Forestry Research 25(3), 637-646.

[15] IPCC., 2007, Climate change 2007: Impacts, Adaptation and Vulnerability. Contribution of Working Group II to the Fourth Assessment Report of the Intergovernmental Panel on Climate Change (IPCC), Cambridge University Press.

[16] ITTO (International Tropical Timber Organization), 2005, Revised ITTO criteria and indicators for the sustainable management of tropical forests. ITTO Policy Development Series No. 15. 
[17] Aguilar-Amuchastegui, N. and Henebry, G.M., 2007, Assessing sustainability indicators for tropical forests: Spatio-temporal heterogeneity, logging, and dung beetle communities. Forest Ecology and Management, 253, 56 - 67.

[18] CIFOR, 2000, Criteria and Indicators for the Sustainable Forest Management: Generic Template. Available online at http://www.cifor.cgiar.org/acm/methods/tool-box $2 . h t m l$ (accessed 25 July 2016).

[19] Franc, A., Laroussinie, O. and Karjalainen, T., 2001, In: European Forestry Institute Proceedings on Criteria and Indicators for Sustainable Forest Management at the Forest Management Unit Level. Available online at http://www.efi.int/files/attachments/publications/proc38_net.pdf. (accessed 10 December 2016).

[20] Finegan, B., Hayes, J. and Delgado, D., 2004, Biological monitoring for FSC-certified forest management in high conservation value forests: a guide for certifiers and forest managers in the humid tropics. WWF-Catie-Proarca, San José, Costa Rica.

[21] Ghazoul, J., 2001, Barriers to biodiversity conservation in forest certification. Conservation Biology, 15, 315 - 317.

[22] Ky-Dembele, C., Tigabu, M., Bayala, J., Ouedraogo, S.J. and Oden, P.C., 2007, The relative importance of different regeneration mechanisms in a selectively cut savanna-woodland in Burkina Faso, West Africa. Forest Ecology and Management, 243, 28 - 38.

[23] Etongo, D., Djenontin, I.N.S., Kanninen, M., Fobissie, K., Korhonen-Kurki, K. and Djoudi, H., 2015, Land tenure, asset heterogeneity and deforestation in southern Burkina Faso. Forest Policy and Economics, 61, $51-58$.

[24] Ouedraogo, I., Savadogo, P., Tigabu, M., Cole, R., Odén, P.C. and Ouadba, J.M., 2009, Is rural migration a threat to environmental sustainability in Southern Burkina Faso? Land Degradation and Development, 20, 217-230.

[25] Driessen, P., Deckers, J. and Spaargaren, O., 2001, Lectures Notes on the Major Soils of the World. Food and Agriculture Organization of the United Nations. Rome: FAO.

[26] Ouedraogo, I., Mbow, C., Balinga, M. and Neufeldt, H., 2015, Transitions in Land Use Architecture under Multiple Human Driving Forces in a Semi-Arid Zone. Land, 4, 60 - 577.

[27] Fontes, J. and Guinko, S., 1995, Carte de Végétation et de L'occupation du sol du Burkina Faso; Projet Campus, UPS, Internationale de la Végétation (ICIV): Toulouse, France.

[28] Sawadogo, L. and Tiveau, D., 2008, Twenty years of experience of joint dry forest management in Burkina Faso. In: Geldenhuys CJ, Ham C, Ham H. (Eds.). Sustainable Forest Management in Africa: some solutions to natural forest management problems in Africa. Proceedings of the sustainable forest management in Africa Symposium. Stellenbosch, South Africa. Available online at http://scholar.sun.ac.za/handle/10019.1/17385 (accessed 11 August 2016).

[29] Dayamba, D., Savadogo, P., Sawadogo, L., Zida, D., Tiveau, D. and Odén, P.C., 2011, Dominant species' resprout biomass dynamics after cutting in the Sudanian savanna-woodlands of West Africa: long term effects of annual early fire and grazing. Annals of Forest Science, 68(3), $555-564$.

[30] MECV, 2009, Cartographie des limites des unites d'amanagement forestiers de Bognounou, Cassou, Nazinon, Sapouy-Bieha, Silly-Zawara-Pouni, Korko-Barsalogo et Yabo. Ouagadougou: Ministere de l'Environnement et de Cadre de Vie.

[31] Nsita, S.A., 2003, Decentralisation and forest management in Uganda: The Intercessional Country-Led Initiative on Decentralisation. Centre for International Forestry Research (CIFOR), Bogor, Indonesia.

[32] MECV, 2004, Contribution du secteur forestière a l'économie nationale et à la lutte contre la pauvreté. Ouagadougou, Burkina Faso: Ministère de l'Environnement et du Cadre de Vie. 
[33] Sawadogo, L., 2006, Adapter les approches de l'amenagement durable des forets seches aux aptitudes sociales, economiques et technologiques en Afrique. Bogor, Indonesia: Center for International Forestry Research (CIFOR), Bogor, Indonesia.

[34] Marušák, R. and Yoshimoto, A., 2007, Comparative Analysis on Cutting Possibilities Derived from Different Allowable Cut Indicators in Slovakia. Available online at http://www.nlcsk.sk/files/3061.pdf (accessed 28 October 2016).

[35] Westholm, L. and Kokko, S., 2011, Prospect for REDD+: Local Forest Management and Climate Change Mitigation in Burkina Faso. Gothenburg, Sweden: Focali.

[36] Agidee, Y., 2011, Forest Carbon in Ghana: Spotlight on Community Resource Management Areas. Washington D.C., USA: Forest Trends.

[37] Etongo, D., Djenontin, I.N.S. and Kanninen, M., 2016, Poverty and environmental degradation in Southern Burkina Faso: An assessment based on participatory methods. Land, 5, 20 Doi: 10.3390/land 5030020.

[38] Amani, K.L., Sam, R. and Zougmoré, F., 2015, Competitiveness level of Photovoltaic Solar Systems in Ouagadougou (Burkina Faso): Study Based on the Domestic Electric Meters Calibration. International Journal of Photoenergy. http://dx.doi.org/10.1155/2016/9698070

[39] Wethe, J., 2009, Energy Systems: Burkina Faso. Vulnerability - Adaptation - Resilience. Paris, France. Available online at http://helio-international.org/wp-content/uploads/2013/12/VARBurkinaFaso.En_.pdf

[40] United Nations Environment Programme (UNEP), 2013, Emissions Reduction Profile Burkina Faso. Available online at www.acp-cd4cdm.org/media/366213/emissions-reduction-profileburkina_faso.pdf (accessed 5 September 2017).

[41] Moner-Girona, M., Bódis, K., Huld, T., Kougias, I. and Szabó, S., 2016, Universal access to electricity in Burkina Faso: Scaling-up renewable energy technologies. Environmental Research Letters, 11, 1-15. Doi:10.1088/1748-9326/11/8/084010

[42] Gunther, B., Michael, G., Max, H., Jörg, L. and Jörg, P., 2016, Are promotion programs needed to establish off-grid solar energy markets? Evidence from rural Burkina Faso. Ruhr Economic Papers, No. 653, ISBN 978-3-86788-759-5. http://dx.doi.org/10.4419/86788759

[43] Bray, D.B., Duran, E., Ramos, V.H., Mas, J.F., Velazquez, A., Mcnab, R.B., Barry, D. and Radachowsky, J., 2008, Tropical Deforestation, Community Forests, and Protected Areas in the Maya Forest. Ecology and Society, 13(2), 56. http://www.ecologyandsociety.org/vol13/iss2/art56/

[44] Njepang, A., 2015, A Structure Analysis for Ecological Management of Moist Tropical Forests. International Journal of Forestry Research http://dx.doi.org/10.1155/2015/161645

[45] Van Laar, A. and Akça, A., 2007, Forest mensuration. In: von Gadow K, Pukkala T, Tomé M. (Eds.) Dordrecht, Springer, The Netherlands.

[46] Sawadogo, L., Tiveau, D. and Robert, N., 2005, Influence of selective tree cutting, livestock and prescribed fire on herbaceous biomass in the savannah woodlands of Burkina Faso, West Africa. Agriculture, Ecosystems \& Environment, 105(1-2), 335-345.

[47] Mitchard, E., Saatchi, S., Gerard, F., Lewis, S. and Meir, P., 2009, Measuring Woody Encroachment along a Forest-Savanna Boundary in Central Africa. Earth Interactions, 13(8), 1 - 29.

[48] Sankaran, M., Hanan, N., Scholes, R., Ratnam, J., Augustine, D. and Cade, B., 2005, Determinants of woody cover in African savannas. Nature, 438, 846 - 849.

[49] FRIG (Forestry Research Institute of Ghana), 2003, Forest fire management in Ghana. Forestry Research Institute of Ghana. Available online at http://www.Final_Technical_Report- ITTO-PD3298F-Ghana.pdf. (accessed 22 July 2016). 
[50] Wily, L. and Mbaya, S., 2001, Land, People and Forests in Eastern and Southern Africa at the beginning of the 21st century. The impact of land relations on the role of communities in forest future. Nairobi, Kenya: IUCN-EARO.

[51] Yadav, N., Dev, O., Springate-Baginski, O. and Soussan, J., 2003, Forest management and utilization under community forestry. Journal of Forest and Livelihood, 3(1), 37-50. 